\title{
Linguistic Imperialism in EFL Teaching: New Role of a Teacher in Educating Generation $\mathrm{Z}$
}

\author{
Anna Astanina, Igor Kuznetsov \\ Chair of foreign languages and educational technologies \\ Ekaterinburg, Russia \\ a.n.astanina@urfu.ru,igor.kuznetsov@urfu.ru
}

\begin{abstract}
In the age of globalization, when all the world is striving for unification, there are special issues that need to be addressed. One of them is the linguistic dominance of European languages (namely English) known as linguistic imperialism which suggests bringing structural and cultural inequalities between languages. Learning a foreign language is closely connected with accepting foreign cultural codes, ideas, practices, and so on making them extremely meaningful to an individual. Here there is a problem of preserving native culture, its values and ideas, which learners have to learn to transfer by means of another language. Learners of the modern English as a foreign language (EFL) are referred to as generation $Z$ and see language skills as a tool necessary to function efficiently in the world. Psychological features of the whole new generation suggest that learners are aware of cultural differences and heritage and are supportive of cultural diversity. In such a case foreign language teachers have to take into account cultural aspects in the educational process and help their learners shape their mindset being protective of their native culture. This brings us to a new function a foreign language teacher acquires, i.e. being a culture preserver. The key is to find the balance in teaching and be sensitive towards the aspects of both native culture of an individual and foreign culture they learn when dealing with another language.
\end{abstract}

Keywords - EFL teaching; linguistic imperialism; generation $Z$; cultural preservation

\section{INTRODUCTION}

The phenomenon of globalization has affected all the aspects of society functioning, bringing new values and mindset to all the society members. Together with the ideas of blurring borders and living in a multicultural society there was a key concept of foreign language proficiency as an indispensable tool for getting a message across and going global. English gained enormous popularity, taking the dominant position among other languages. Being an official language in a vast majority of countries, English strengthened its position by becoming a leading tool of academic research publication, international tourism and work.

A few researchers, however, became concerned about the status-quo of the English language and the changes it had brought to the forefront. One of the pioneering scholars in that sphere is Robert Phillipson. In his notable book "Linguistic Imperialism" Phillipson has coined a new term of linguistic imperialism which he defined as "the dominance of English asserted and maintained by the establishment and continuous reconstitution of structural and cultural inequalities between English and other languages" [1].

The term itself got a sufficient amount of criticism. Nevertheless, lately a shift in perception of language role and linguistic dominance has been observed. A new generation of language users (referred to as "generation Z") has brought significant changes to the ideas of linguistic imperialism. These changes could not but make an impact on the way English is taught: teachers have to both help English language learners to develop their skills and navigate in the cultural aspects of various peoples around the world. With this in mind, we believe it is reasonable to speak about a new role of a teacher as a culture - preserver when we speak about face-toface teaching or blended learning as opposed to purely online courses provided without teacher's guidance.

\section{METHODS AND MATERIALS}

The main research method used in the article is the critical analysis of literature and practical experience.

\section{A. Linguistic Imperialism Perception}

Phillipson's definition raises the question of linguistic dominance of the English language over the mother tongues around the world and the changes connected with the orientation the western values associated with linguistic competence. Structural inequality pertains to material properties, e.g. institutions, financial allocations while cultural inequality relates to immaterial or ideological properties, e.g. attitudes and pedagogical principals [1]. Phillipson posits that the English linguistic imperialism represents linguicism, i.e. "ideologies, structures, and practices which are used to legitimate, effectuate, and reproduce an unequal division of power and resources (both material and immaterial) between groups which are defined on the basis of language" [1]. For instance, such structural and cultural inequalities provide for prolonged distribution of material resources towards English compared to other languages and those with proficiency in English [1]. It is fair to concur with Canagarajah and Said as well who exemplify denigration of indigenous languages by 
colonizers through their "discourse that English is a superior language with the capacity to express complex philosophical, scientific, and technical information" [2]. As soon as colonized multi-lingual communities would start to internalize this narrative and learn English at the cost of their native tongues they would acquire knowledge, identities and values expressed in English and thus reinforce the power entertained, in this case, by the Anglophone countries [2].

Such prevalence of foreign cultural codes over the native ones, making them meaningful since childhood raises the question of preserving national heritage and culture, as "there is a certain deformation of national linguistic and cultural concepts with their partial substitution by those of another culture, another society" [3].

The ascendance of the USA as a sole superpower after the collapse of the Soviet Union has led some scholars to believe it is now a new benevolent empire based on democracy and freedom of markets of any sorts. Fukuyama declared the ideological 'end of history' resulting from the victory of the Western liberal democracies over communism (Fukuyama, 1989). Western values have been declared universal for any human around the world and the USA being the custodian of them. Hence it is possible to export them via different routes, not least through promoting English at a very large scale.

David Rothkopf, the director of the Kissinger Institute later voiced the messianic idea that cultural imperialism is not so bad for the world and the USA should not stay away from promoting its exceptionalism and values, albeit in its economic, political and security self-interest: "In an effort to be polite or politic, Americans should not deny the fact that of all the nations in the history of the world, theirs is the most just, the most tolerant, the most willing to constantly reassess and improve itself, and the best model for the future." [4].

It is obvious that the promotion of American or AngloAmerican values is best done in English. Rothkopf went on: "It is in the general interest of the United States to encourage the development of a world in which the fault lines separating nations are bridged by shared interests. And it is in the economic and political interests of the United States to ensure that if the world is moving toward a common language, it be English; that if the world is moving toward common telecommunications, safety, and quality standards, they be American; that if the world is becoming linked by television, radio, and music, the programming be American; and that if common values are being developed, they be values with which Americans are comfortable. These are not simply idle aspirations. English is linking the world. American information technologies and services are at the cutting edge of those that are enabling globalization. Access to the largest economy in the world - America's - is the primary carrot leading other nations to open their markets."[4].

Peters argued in no uncertain, but rather cynical, degrading and bellicose terms that "the contemporary expansion of available information is immeasurable, uncontainable, and destructive to individuals and entire cultures unable to master it... For those individuals and cultures that cannot join or compete with our information empire, there is only inevitable failure (of note, the internet is to the techno-capable disaffected what the United Nations is to marginal states: it offers the illusion of empowerment and community) ... These non-competitive cultures, such as that of Arabo-Persian Islam or the rejectionist segment of our own population, are enraged. Their cultures are under assault; their cherished values have proven dysfunctional, and the successful move on without them." [5].

Milne provides an example of this strategy in action where the current hegemon the USA and two former colonizers France and Britain are engaged in a new partitioning of Africa in the name of securing resources and influence to oppose China's growing role [6].

Still, some authors seemed to see American cultural imperialism acceptable even towards Britain. Some aspects of this imperialism like urban fashion, pervasive pop music, multiple Hollywood blockbusters are appealing. Some of them like the obesity epidemic are clearly not. Ironically enough, both have been appropriated so well in the UK that one might view Great Britain as the ultimate example of Americanization [7]. It is plain to see that this extensive spread of America's mass culture in the United Kingdom is largely facilitated by the shared English language. It is a fascinating avenue for further research, including linguistic aspects of 'Americanization' of Britain.

Phillipson associates the current status of English with neo-imperialism and globalization. A number of quasigovernmental organizations and some philanthropy funds like Ford Foundation have been involved in promoting English worldwide. However, some not so overtly stated goals and discourses associated with global economic and political dominance of English-speaking countries have been pursued as well [8]. In Lin and Luke's view “colonization's legacy has become invisible ideological hegemony - domination with consent; that is, the previously colonized peoples still worship the languages, cultures, music, arts, knowledge, pedagogies, or most aspects of Western life as more advanced, progressive and superior - as lying closer towards the end point of modernity" [9].

The idea that the EU as an organization should use English as the only official language has been expressed before. It is somehow implied that it is in everyone's interest that English is synonymous with globalization. Phillipson cites the American ambassador to Denmark who stated that "the most serious problem for the European Union is that it has so many languages, this preventing real integration and development of the Union" [10]. The Director of the British Council in Germany in his turn suggested that "English should be the sole official language of the European Union" [10]. It is difficult to accept such statements. Hopefully, the EU will stay committed to its policy of language plurality in the foreseeable future. However, the Nordic and Eastern European countries have experienced the hegemonic linguistic impact of English in the academic publishing domain. As evidenced by Mendieta et al. more and more research done in these countries is published in English effectively excluding or downgrading research reported in first languages. Scholars conducting and reporting their research in English are most likely to use methodologies prescribed by Anglo-American academic tradition, which 
might skew the end results. Mendieta et al. cite Kachru to illustrate this biased and "tunnel vision" approach stemming from omnipresence of English in the academic journal publishing:

"This is a typical specimen of Indian and Western collaboration: superficial and patronising [...] By ignoring scholarship in India's regional languages on India's language issues, we are missing vital insights. The English language provides us just one dimension, one perspective and one window." [11].

In fact, the necessity to publish the results of their research in another language urges modern scientists to both master their language skills and comply with the rules of foreign writing traditions [12]. Traditions of academic writing, for example, differ greatly in Russian and in English but the scholars have to spend a sufficient amount of time to write their articles in a "western" manner to get visibility in on a global scale. However, if the results are published in the native language, do they lose their value for the academic society?

Thus, we face a dilemma: on the one hand, using one language provides some guarantee of being understood in any part of the global community, as all the participants are supposed to be proficient (to a greater or lesser extent) in one language; on the other hand, there is a big chance of losing national integrity, giving up on linguistic (and broader, cultural) legacy. That is a multi-aspect challenge that needs to be addressed.

\section{B. The Era of Generation $Z$}

The issue of language learning cannot be considered without taking into account the features of a contemporary learner. Despite huge interest in the topic, there have been few scientific publications on it so far not to mention some wellgrounded research.

Yet, those articles presented in scientific journals picture an English as a foreign language (EFL) learner as a young individual -usually a representative of generation $\mathrm{Z}$ - people born in the period 1996-2012 [13]. In their article Schwieger and Ladwig analyze the data published in various reports by well-known companies on features of future employees, i.e. generation $\mathrm{Z}$ representatives. Having examined survey results, the authors come up with a list of characteristics to define generation $\mathrm{Z}$ people. According to the research results, this generation values fairness and trusts employers to be reasonable, they also try to find their way in life by becoming entrepreneurs and showing their independence and selfsufficiency. They are inspired by others' stories and have a strong tendency to share their experiences, openly discuss ideas and opinions and stay connected. In case they have to work as a part of a team they believe it is their managers' responsibility to promote team building to establish a strong connection among the members of the group. These findings are in accordance with other research data [14] stating that generation $\mathrm{Z}$ workers are keen project developers and like working in teams, provided that their opinions and ideas are listened to and taken into account by their managers.
Generation $\mathrm{Z}$ is often accused of being consumer society. In fact, they do buy, but prefer to do it online as such a way is "efficient, seamless and error-free". This is applicable to consuming services, as well, e.g. educational resources and courses. Due to being efficient, user-friendly, various and reasonably priced, online courses and certificates are popular among youngsters.

In terms of education one cannot but mention pragmatism of post-millenials. They are referred to as hard-working, practical, creative, persistent, ambitious, realistic strong individuals who seek for new knowledge and experience and are sure that every attempt should be rewarded (by reasonable salary, a certificate, etc.). In order to be efficient they make use of every source available, the Internet is viewed as an immense source of information.

Thanks to being born and raised in the period of rapid technological development young people are familiar with various gadgets and make an active use of their smartphones not to show their superiority or boast but rather because of necessity to get immediate access to the information they need. Their perception of the technological items is purely functional [15]. Learners are also aware that they "have more technology know-how than their lecturers" [16], which imposes a new set of requirements on organising the process of education. Not only are the teachers challenged to be technologically proficient, but they are expected to adapt their way of teaching and provide materials in electronic form, at least it concerns lecture material and electronic examinations. Such a way of organising the educational process gives an opportunity for the learners to access the necessary teacherchosen content from anywhere getting ready for the organised contact sessions in the classroom.

Last but not least, gen $\mathrm{Z}$ shows a completely different way of understanding cultural environment they act in. On the one hand, they are concerned with their own (traditional) culture and they associate themselves with ethnicity (they are aware of their minority status and possible bullying in the workplace because of this) hugely relying on their family and friends' support [17]. On the other hand, they understand and respect other cultures and minorities. They may also choose a set of characteristics from multiple cultures mixing religious ideas, dressing features, attitudes from various beliefs to make themselves unique and stand out from the crowd. By doing this they represent their understanding and support of cultural, ethnic, religious and other diversity.

All the above-mentioned characteristics point at mostly positive features of being a gen $\mathrm{Z}$ representative. However, researchers also underline a number of problems postmillenials show their concern about: discrimination of various sorts (racial, age, gender, etc.), working conditions, freedom limitation, etc. Interestingly enough, young people from institutions preparing hospitality workforce pointed out they were concerned with their possible inability to perform the job in live environment, which was dramatically different from the results of the previous studies pointing at gen $\mathrm{Z}$ selfconfidence [18].

Thus, the results presented in the research papers devoted to generation $\mathrm{Z}$ provide both similar and contradictory 
characteristics to refer to the new generation. In any case, teaching them we need to adapt to their needs and characteristics to help them get the most of their learning experience.

\section{RESULTS AND DISCUSSION}

Let us now carefully examine the situation from a teacher's perspective. A teacher is responsible for choosing the right content to help students broaden their knowledge of the world around and develop their skills and competencies to act as effective members of contemporary society. Moreover, the EFL teachers provide the learners with a tool (a foreign language) to act adequately in globalized environment. Teaching a foreign language we teach to acquire and transfer a new code, a system of values and notions of a culture different from our native one, in many cases dramatically different from ours.

But here we find a paradox: by using this new system of codes and values a teacher should facilitate a learner's ability to transfer their cultural background into the world. In other worlds, an EFL learner must be able to describe aspects of their own culture by means of unfamiliar tools (sounds, words, grammatical categories). More surprisingly, in the process of acquiring a foreign language with all the cultural background one inevitably starts comparing the two cultures (native and foreign ones) but there is a danger to stick to the point that some culture might be superior to another one.

In this case a teacher should use all their skill to help the learners develop a balanced view of cultural phenomena expressed through language together with teaching EFL. We usually see the role of a teacher in transferring or "giving" knowledge to their students. In reality one needs to remember that modern EFL teaching is not limited by making learners memorise vocabulary and grammar but rather help them develop a set of receptive and productive skills. EFL teachers first make sure that the learners have acquired the basics of the language they learn to be able to express some ideas. Later they encourage the learners share their ideas and experiences from the point of view of their native culture. Ideally a group of learners can comprise learners from different countries, which might provide the "real-life" necessity for learners to describe "how they do it in their country". It is both educational and practically-oriented experience.

Even in situations of monolingual environment teachers eagerly employ games with various cultural references (roles to encourage their learners think differently, learners are made to take part in projects aiming at presenting festivals/ customs/ clothes, etc. of peoples around the world). Modern methodology also takes into account the trend of recognising cultural diversity and EFL textbooks nowadays contain information about cultural features of different peoples as well as special tasks of comparing some facts or phenomena presented in the course with those of the learner's native culture. Such tasks cannot be skipped as they show the learners the importance of their own culture in the globalised world. The role of a teacher then is to promote cultural sensitivity in their learners and to help them be proud of their historical and cultural heritage, which they can transfer to the world by using an international language. In other words, it may be true to say that an EFL teacher performs a role of a culture-preserver.

\section{CONCLUSION}

In today's globalised world where English (or any other popular foreign language) dominates, bringing structural and cultural inequalities, it is vital to learn to minimise the impact of other cultural values and codes on the native culture. It may seem quite challenging taking into account that modern learners of foreign languages are aware and tolerant towards cultural diversity. From this perspective, EFL teachers can be considered culture-preservers as they help learners to both develop necessary competencies to act adequately in the world and to encourage the idea of protecting native culture and historical heritage of the learners themselves.

\section{References}

[1] R. Phillipson, Linguistic Imperialism . Oxford University Press: Oxford, 1996.

[2] S. Canagarajah, S. Ben Said, Linguistic Imperialism. The Routledge Handbook of Applied Linguistics, Chapter: 27, Routledge, 2011, pp.388-400

[3] H.V. Shelestiuk, "Westernisation in the USSR and Russia: analysis of the causes", Inostranniy yazyk v sisteme srednego i vysshego obrazovaniya, Foreign language in the system of secondary and higher education, pp. 71-79, October 2013 [Materials of III international conference Vědecko vydavatelské centrum «Sociosféra-CZ», p.216, 2013]

[4] D. Rothkopf, "In Praise of Cultural Imperialism?", Foreign Policy. No.107 (Summer), pp. 38-53, 1997.

[5] R. Peters, "Constant Conflict", Parameters, Vol. 40, No.4, 2010.

[6] S. Milne. "Coups and terror are the fruit of NATO's war in Libya", The Guardian. May 22nd. 2017.

[7] S. Heffer, "America is the acceptable face of cultural imperialism". The Telegraph. July 24th. 2010.

[8] R. Phillipson, English, the lingua nullius of global hegemony. The politics of multilingualism: linguistic governance, globalisation and Europeanisation, ed. François Grin \& Peter A. Kraus. John Benjamins: Amsterdam., 2014, pp. 275-303.

[9] A. Lin, A. Luke, "Coloniality, Postcoloniality, and TESOL. . Can a spider weave its way out of the web that it is being woven into just as it weaves?" Critical Inquiry in Language Studies. Vol.3, issue 2-3, pp. 6573, 2006

[10] R. Phillipson, "The Linguistic Imperialism of Neoliberal Empire", Critical Inquiry in Language Studies. Vol.5, No.1, p1-43, 2008

[11] E. Mendieta, R. Phillipson, T. Tove Skutnabb-Kangas, "English in the geopolitics of knowledge", Revista Canaria de Estudios Ingleses. No.53, pp.15-26, 2006.

[12] I. B. Korotkina, "Russian scholarly publications in anglophone academic discourse: the clash of tyrannosaurs", Integratstiya obrazovaniya, Integration of education, vol 22 (2), pp.311-323, 2018

[13] D. Schwieger, C. Ladwig, "Reaching and retaining the next generation: adapting to the expectations of gen $\mathrm{Z}$ in the classroom", Information Systems Education Journal, vol 16(3), pp.45-54, 2018.

[14] M. Ozkan, B. Solmaz, "The changing face of the employees - generation $\mathrm{Z}$ and their perceptions of work (a study applied to university students)". Procedia- Economics and finance 26, pp. 476-483, 2015.

[15] M. Ozkan, B. Solmaz, "Mobile addiction of generation $\mathrm{Z}$ and its effects on their social lives (an application among university students in the 1823 age group)", Procedia- Social and behavioral sciences, Vol .205, pp. 92-98, 2015. [6th World conference on psychology counseling and guidance, 14-16 May 2015] 
[16] E.J. Cilliers, "The challenge of teaching generation Z", People: international journal of social sciences, special issue vol. 3 , issue $1, \mathrm{pp}$ 188-198, 2017.

[17] E. Goh, F. Okumus, "Avoiding the hospitality workforce bubble: strategies to attract and retain generation $\mathrm{Z}$ talent in the hospitality workforce", Tourism management perspectives, Vol. 33, in press, 2020.
[18] E. Goh, C. Lee, "A workforce to be reckoned with: the emerging pivotal generation $\mathrm{Z}$ hospitality workforce", International journal of hospitality management, Vol. 73, pp. 20-28, 2018 